\title{
Modeling and Control of Hybrid Power Sourced High Gain DC-DC Converter
}

\author{
Y. Ravindranath Tagore
}

Electrical \& Electronics Department, RVR \& JC College of Engineering, Chowdavaram, 522019, Guntur, Andhra Pradesh, India.

Received 17 December 2020; Accepted 23 January 2021

\begin{abstract}
Solar energy plays a key role in feeding many electric loads such as households, education institutions and industrial applications. On the other hand, the fuel cells can realize zero emission power, enhanced efficiency, low operational costs and scalability. However, the inferior quality associated with the fuel cells (FCs) and solar cells is the production of a very low output voltage. Therefore, high gain step-up converters are required to get the desired dc voltage levels. This paper emphasizes the performance of a hybrid power sourced step-up converter. The FC polarisation and cell voltage characteristics are shown with a focus on the temperature effects. The modeling aspects of the solar PV panel are also presented in detail. The high gain converter dynamics are interpreted with the voltage-mode control (VMC) and averagecurrent mode control (ACMC) approaches. The simulation results are presented by considering various case studies in view of the line and load regulations.
\end{abstract}

Keywords: Solar PV panels, fuel cells, DC-DC converters, control strategies.

\section{Introduction}

Nowadays, the usage of renewable energies such as solar, wind and hydrogen has been speeded up throughout the world. Solar energy is a clean and inexhaustible resource of energy where no greenhouse gas emissions are released into the atmosphere. They have the potential to replace fossil and gas based power generation plants, analysed by Guangul and Chala [1]. The solar energy is mainly used to produce electricity for homes and businesses. Solar energy can be stored in the battery or can be fed to the grid. The operational costs are quite low compared to the other types of power generation. It is also important to use specific materials for manufacturing solar panels. Moreover, the output from the solar panel should be fed to proper power conditioning units (PCUs) such as high gain step-up converter followed by the inverter. On the other hand, the fuel cells (FCs) are used as an alternative energy source in many applications such as Electric Vehicles (EVs), commercial and industrial buildings. An FC produces electrical energy by combining hydrogen and oxygen to form water and heat as by-products as analysed by Tagore et al. [2]. The FCs has the following outstanding features.

- Low emissions

- Modularity

- Multi-fuel flexibility

- High reliability

- Durability

- Scalability and flexible siting

Batteries are capable of providing large amounts of power quickly and are less sensitive to current ripples. Whereas, the FCs are not able to meet the sudden load demands with a large time constant. Moreover, they are highly sensitive to current

*E-mail address: yrtagore@gmail.com.

ISSN: 1791-2377 @ 2021 School of Science, IHU. All rights reserved. doi:10.25103/jestr.141.14 ripples. Hence, it is important to design an efficient PCU along with a pertinent control strategy as reviewed by Shekhar et al. [3]. The PCU bandwidth should not be more than that of the FC. This PCU should be able to see the temperature and hydration level of the FC in order to avoid faulty operations. Not only this, the other downside is associated with the generation of the very low output voltage. This voltage is also affected by different internal losses such as ohmic, activation, mass transportation effects. On the other hand, solar energy also plays a key role in feeding the electric loads. Each solar cell produces very little voltage and therefore needs many cells to be connected in series. Hence, these two cases necessitate an attractive high gain step-up converter for producing the desired dc link voltage for the DC-AC converter. Many step up converters are reported in the literature, introduced by Zhang et al. [4, 5], Kardan et al. [6]. Some converters lack of providing high conversion ratios. Also, the voltage stresses of the power semiconductor devices are not that favourable. This increases device ratings which further enhances the cost of the overall system. Importantly the efficiency and converter cost is also affected by the number of its constituent devices. Hence, there should be a compromise between the number of components and achievable conversion ratio satisfying the required features for a suitable dc-dc converter as emphasized by Zhang et al. [7], and Ismail et al. [8]. Normally, the switched capacitor converters are efficient in providing more voltage gain. But they are unable to provide better output voltage regulation. On the other hand, the switching mode dc-dc converters enable good voltage regulation. But their downside is the poor high voltage gain. In order to overcome the drawbacks in switched capacitor converters as well as switching mode converters, various novel converter topologies were introduced by $\mathrm{Wu}$ and Ye [9]. Out of many reported topologies, this paper highlights the design of a Type-I boost/buck-boost based High Gain Converter (HGC). It has a total number of two capacitors namely boost capacitor and buck-boost capacitor. This HGC is implemented with a simple and one loop voltage-mode control (VMC). However, this paper introduced the average-current 
mode control (ACMC) with outstanding features like overcurrent protection, fast dynamics and no subharmonic oscillations, emphasized by Yadlapalli and Kotapati [10]. The converter dynamics are interpreted with the VMC and ACMC control approaches. The design aspects are fulfilled for the above two control strategies. The simulation results are presented by considering various case studies in view of the line and load regulations. This paper is organized as follows; Section 2 gives modeling aspects, and the simulation results in Section 3. Section 4 gives the conclusions.

\section{Block diagram of the proposed scheme and system modeling}

Fig. 1 shows the schematic of the proposed system. This system can be fed either from the solar PV module or Air Breathing Fuel Cell (ABFC) stack. Both the energy sources are connected to the system through a distinctive high gain DC-DC converter.

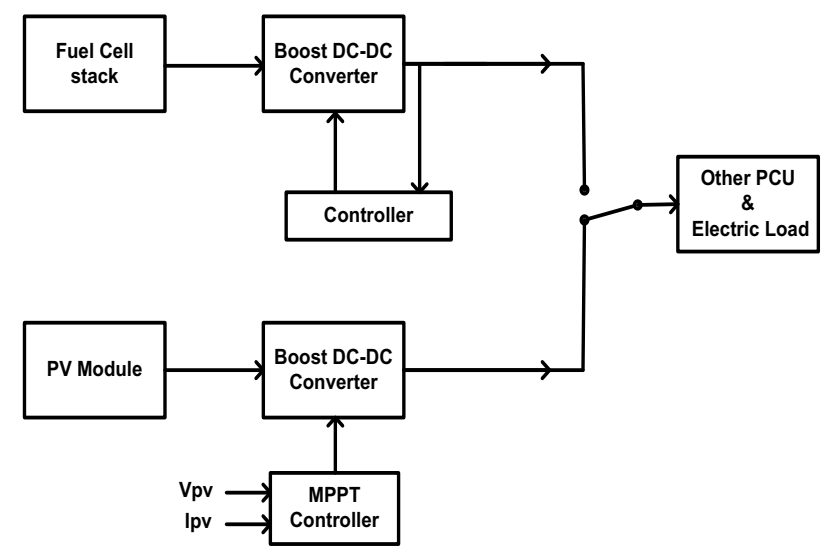

Fig. 1. Proposed power system block diagram

A Type-I boost/buck-boost based high gain converter shown in Fig. 2, introduced by Wu et al. [9]. This HGC has the input-output voltage relations given by:

$\frac{V_{O}}{V_{\text {in }}}=\frac{2}{1-D}$

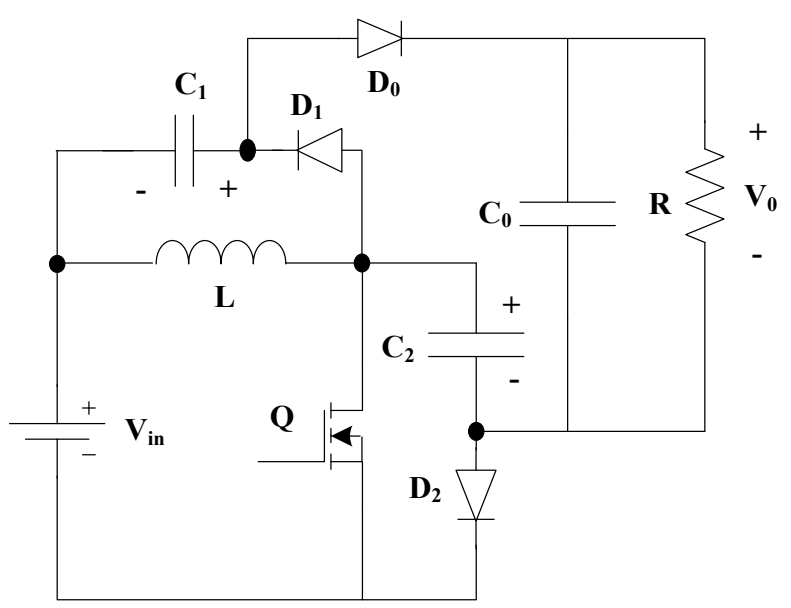

Fig. 2. Schematic of HGC [9]

\subsection{Fuel Cell Model}

At standard state conditions, the FC potential is around 1.229 V. But, from this equilibrium value, there is a downfall due to different drops such as activation, ohmic, and concentration losses. Eqs. (2) - (17) present the FC output voltage, introduced by Tagore et al. [2]. Eq. (2) represents the operating FC voltage in terms of open circuit voltage, activation, ohmic and concentration losses.

$V_{\text {Fuelcell }}=V_{\text {Opencircuit }}-\Delta V_{\text {Activation }}-\Delta V_{\text {Ohmic }}-$

The FC open circuit voltage is given in terms of the Nernst and crossover potentials.

$\mathrm{V}_{\text {Opencircuit }}=\mathrm{V}_{\text {Nernst }}-\mathrm{V}_{\text {Cross }}$

$V_{\text {potentialNernst }}=1.482-0.000845 * T+0.0000431 *$

$T * \ln \left(\rho_{\mathrm{H}_{2}} * \rho_{\mathrm{O}_{2}}{ }^{0.5}\right)$

$V_{\text {Cross }}=\frac{R T}{\alpha F} \ln \left(\frac{i_{\text {Cross }}}{i_{0}}\right)$

$\rho_{H_{2}}=\frac{0.5 P_{H_{2}}}{\exp \left(\frac{1.653 * i}{T_{A D P}^{1.334}}\right)}-P_{S a t}$

$\rho_{O_{2}}=\frac{P_{O_{2}}}{\exp \left(\frac{4.192 * i}{T_{G D P}^{1.334}}\right)}-P_{S a t}$

$P_{\text {Sat }}=10^{\left(+1.4454 * 10^{-7} * T^{2}-9.1837 * 10^{-5} * T^{2}-2.1794+0.02953 * T\right)}$

Eqs. (9) - (10) give the activation loss of the FC.

$V_{\text {Activation }}=\frac{R T}{\alpha F} \ln \left(\frac{i}{i_{0}}\right)$

$\Delta V_{\text {Activation }}=\frac{R T}{\alpha F} \ln \left(\frac{i+i_{c r}}{i_{0}}\right)$

The ohmic and concentration losses are expressed by the Eqs. (11) - (17).

$\Delta V_{\text {Ohm }}=i * r_{\text {Ohm }}$

$r_{\text {Ohm }}=r_{\text {resistanceAnode }}+r_{\text {resis tanceCathode }}+$

$r_{\text {resis tan ceIonic }}+r_{\text {resis tan ceContact }}$

$r_{\text {resis tanceAnode }}=\frac{\rho_{G D L * L_{G D L}}}{A_{\text {cellarea }}}+\frac{\rho_{G r * L_{G r}}}{A_{\text {cellarea }}}$

$r_{\text {resistan ceCathode }}=\frac{\rho_{G D L * L}}{A_{\text {cellarea }}}+\frac{\rho_{G r * L}}{A_{\text {cellarea }}}$

$r_{\text {Ionic }}=\frac{L_{\text {Membrane }}}{\sigma A_{C}}$

$\sigma=(-0.00326+0.005169 * \lambda) * \exp \left(\left(-\frac{1}{T}+\frac{1}{303}\right) 1268\right)$

$\Delta V_{\text {Concentration }}=\frac{T R}{F n}\left(\frac{1}{\alpha}+1\right) \ln \left(\frac{i_{L}}{-i+i_{L}}\right)$

Where $\mathrm{L}, \mathrm{r}, \mathrm{T}, \rho$ and $\mathrm{A}_{\mathrm{C}}$ are the membrane thickness $(\mathrm{cm})$, ohmic resistance $\left(\Omega-\mathrm{cm}^{2}\right)$, cell temperature $(\mathrm{K})$, specific resistance, $(\Omega-\mathrm{cm})$ and cell area $\left(\mathrm{cm}^{2}\right)$, respectively.

\subsection{Photovoltaic Module}

Fig. 3 depicts the solar PV cell equivalent circuit based on Eqs. (18) - (21). The $\mathrm{I}_{\mathrm{ph}}, \mathrm{N}, \mathrm{K}, \mathrm{q}, \mathrm{a}, \mathrm{T}, \mathrm{G}, \mathrm{R}_{\mathrm{se}}$, and $\mathrm{R}_{\mathrm{sh}}$ give the photo current of the cell, the number of cells, Boltzmann's constant, charge of electrons, ideality factor, temperature, 
solar irradiation, series and shunt resistances, respectively, as emphasized by Ganesh et al. [11], Ravindranath and Anuradha [12].

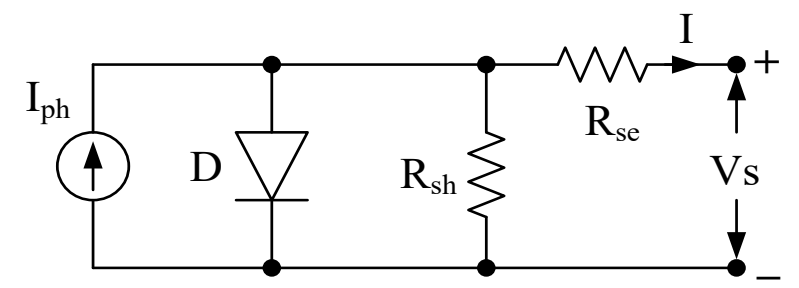

Fig. 3. Equivalent circuit of PV cell

The photon current, reverse saturation current and saturation current of the PV module are expressed by

$I_{\text {photon,PV }}=\left[I_{s c r, P V}+K_{i}(T-298)\right] * \frac{G}{1000}$

$I_{\text {reversesaturation }, P V}=\frac{I_{s c r, P V}}{\left[\exp \left(\frac{q v_{O C}}{N_{S} \mathrm{KaT}}\right)-1\right]}$

$I_{\text {saturation }, P V}=I_{\text {reversesaturation, } P V}\left[\frac{T}{T_{r s}}\right]^{3} \exp \left[\frac{q_{e^{*} E_{g}}}{a K}\left\{\frac{1}{T_{r s}}-\frac{1}{T}\right\}\right](20)$

Eq. (21) yields the module current output.

$I_{P V}=N_{\text {parallel }} * I_{\text {ph,PV }}-N_{\text {parallel }} * I_{\text {saturation }}\left[\exp \left\{q_{e} *\right.\right.$

$\left.\left.\frac{V_{P V}+I_{P V} R_{S}}{N_{\text {series }} \mathrm{KKT}}\right\}-1\right]$

\section{Simulation results}

The literature presents the ABFC simulation parameters [12] as shown in Tab. 1. Tab. 2 [11] presents the $217.35 \mathrm{~W}$ solar PV module electrical characteristics, that powers the HGC with maximum power point tracking (MPPT) based on Perturb \& Observation ( $\mathrm{P} \& \mathrm{O}$ algorithm). The HGC simulation parameters [9] are depicted in Tab. 3. The simulation is performed using PSIM software version 6.0. PSIM software can be interfaced with the MATLAB/Simulink through a SimCoupler.

Fig. 4 presents the single FC polarisation as well as cell voltage characteristics. The drop in the cell voltage at low, medium and high current densities is followed by the activation, ohmic and concentration losses respectively. There is a drop in the cell potential of $0.71 \mathrm{~V}$ for the current density change from zero to $100 \mathrm{~mA} / \mathrm{cm}^{2}$. The power density (PD) curve plays a prominent role while selecting the FCs in various power system applications. The size of the system greatly relies on the PD. The portable applications need high PDs where efficiency may not be the superior criteria. In power generation applications, higher efficiencies are required other than the size of the system.

Each FC produces a voltage of around $0.56 \mathrm{~V}$. Therefore, $81 \mathrm{FCs}$ are required in order to produce an output voltage of nearly $45 \mathrm{~V}$ for powering the HGC. Fig. 5 and Fig. 6 present the output voltage of a single FC and FC stack.

The FCs are subjected to internal parameter variations as well as external sudden load disturbances. The immediate effect is the drop in the FC potential. Therefore, the transient response study of the FC is extremely useful for real-time control and optimal design of FCs in power system applications. In view of this, Fig. 7 and Fig. 8 show the effect of temperature on the FC performance.

The FC voltage and stack voltage increases by $0.025 \mathrm{~V}$ and $2.00 \mathrm{~V}$ for a step decrement in the cell temperature from $40^{\circ} \mathrm{C}-30^{\circ} \mathrm{C}$. The FC voltage and stack voltage falls by 0.025 $\mathrm{V}$ and $2.00 \mathrm{~V}$, respectively for a step increment in the cell temperature from $40^{\circ} \mathrm{C}-50^{\circ} \mathrm{C}$. In the above two cases, the settling time of the FC voltage is less than few msec with respect to the temperature variations.

Table 1. ABFC nominal parameters

\begin{tabular}{l|l}
\hline Parameter & Value \\
\hline $\begin{array}{l}\rho \text { of Gas Diffusion Layer } \\
\text { (GDL) }\end{array}$ & $0.0017 \Omega-\mathrm{Cm}$ \\
$\begin{array}{l}\text { Thickness of GDL } \\
\rho \text { of Graphite }\end{array}$ & $0.036 \mathrm{Cm}$ \\
Thickness of Graphite & $0.00231 \Omega-\mathrm{Cm}$ \\
Flow Channel & $0.1 \mathrm{Cm}$ \\
$\mathrm{L}$ & \\
$\lambda$ & $0.0178 \mathrm{Cm}$ \\
icr & 12 \\
$\mathrm{r}$ & $3.0 \mathrm{~mA} / \mathrm{Cm} 2$ \\
\hline
\end{tabular}

Table 2. Solar panel simulation parameters

\begin{tabular}{l|l}
\hline Nominal Parameter & Value \\
\hline$P_{r a}$ & $217.35 \mathrm{~W}$ \\
$V_{p}$ & $45 \mathrm{~V}$ \\
$I_{p}$ & $4.83 \mathrm{~A}$ \\
$V_{o c}$ & $51 \mathrm{~V}$ \\
$I_{s c}$ & $5.18 \mathrm{~A}$ \\
$N_{s}$ & 27 \\
$N_{p}$ & 1 \\
\hline
\end{tabular}

Table 3. Specifications of HGC

\begin{tabular}{l|l}
\hline Nominal Parameter & Value \\
\hline$V_{\text {in }}$ & $45 \mathrm{~V}$ \\
$\mathrm{~L}$ & $220 \mu \mathrm{H}$ \\
$C_{1}=C_{2}$ & $1.25 \mu \mathrm{F}$ \\
$C_{o}$ & $400 \mu \mathrm{F}$ \\
$f_{s w}$ & $100 \mathrm{kHz}$ \\
$V_{0}$ & $400 \mathrm{~V}$ \\
Load $R_{\text {min }}-R_{\max }$ & $800 \Omega-4000 \Omega$ \\
\hline
\end{tabular}

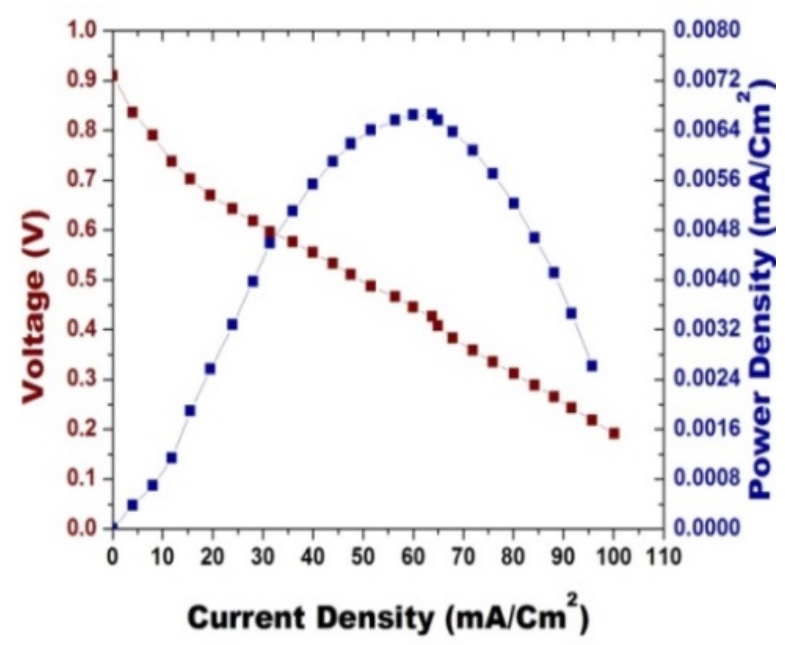

Fig. 4. ABFC polarisation characteristics 


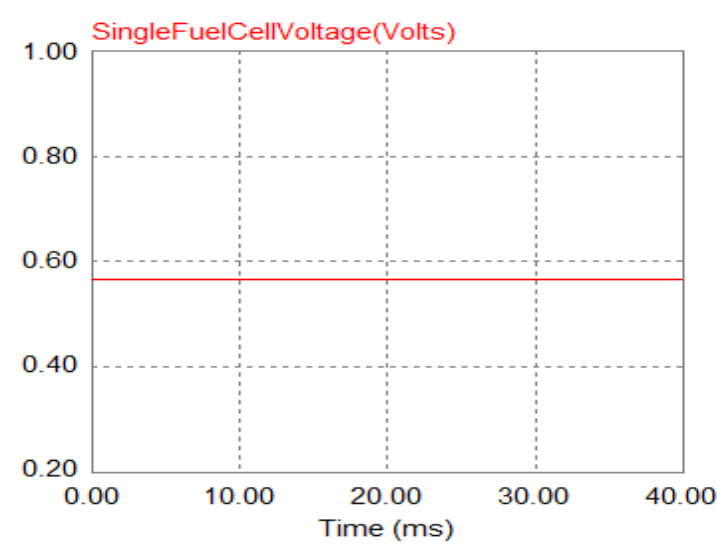

Fig. 5. Single FC voltage waveforms

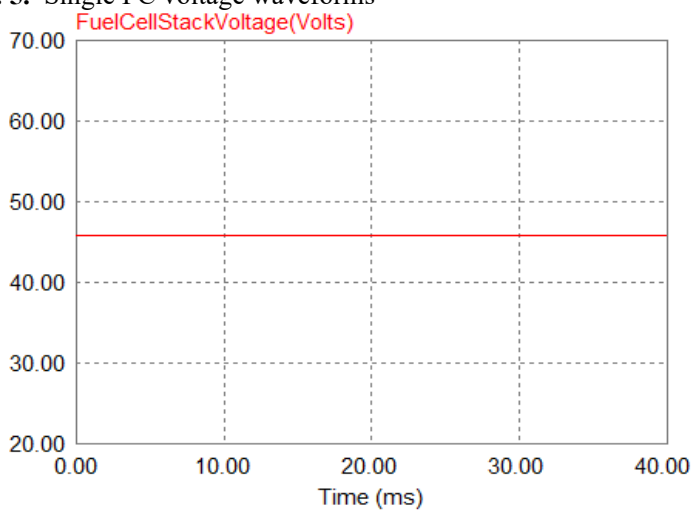

Fig. 6. FC Stack voltage waveforms

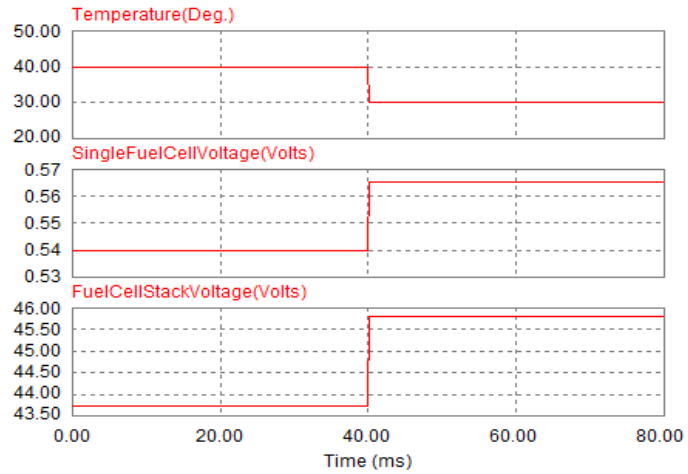

Fig. 7. Effect of temperature on $\mathrm{FC}$ performance for $40^{\circ} \mathrm{C}-30^{\circ} \mathrm{C}$ step change

The polarization phenomenon is caused by various physical and chemical factors and limits the FC reaction process whenever there is a current flow through the FC.

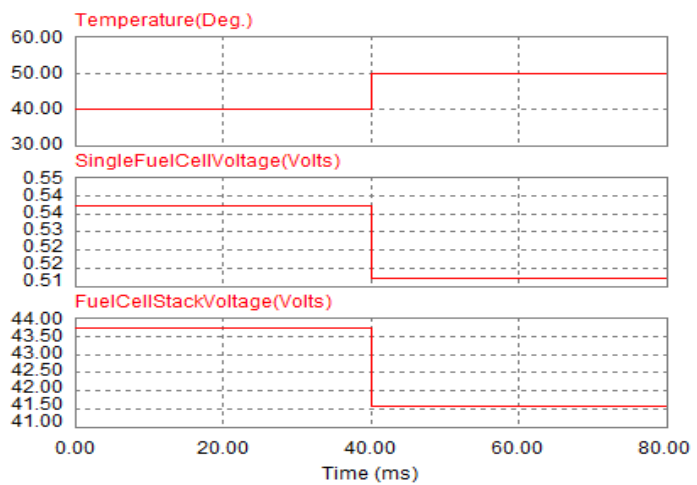

Fig. 8. Effect of temperature on $\mathrm{FC}$ performance for $40^{\circ} \mathrm{C}-50^{\circ} \mathrm{C}$ step change
As mentioned earlier, the utilization of solar energy is dominant in many domestic as well as industrial applications. However, the solar irradiation is not constant and varies throughout the day. Hence, it is important to track maximum power from the solar PV panel with varying solar irradiations. Figs. (9) - (12) highlight the P-V, I-V and MPPT performance characteristics. These curves are shown for the solar irradiation variation from $200-1000 \mathrm{w} / \mathrm{m}^{2}$.

Moreover, the Maximum Power Point Tracking (MPPT) controller should extract maximum power with a high speed and accuracy. The MPPT controller performance is analysed for a step increment in solar irradiation from $400-1000 \mathrm{w} / \mathrm{m}^{2}$ at $\mathrm{t}=2 \mathrm{sec}$ and thereafter $1000-400 \mathrm{w} / \mathrm{m}^{2}$ decrement in two steps at $\mathrm{t}=4$ and $7 \mathrm{sec}$ as shown in Fig. (11). Fig. (12) highlights the transient response of the MPPT controller with a settling time of few msec.

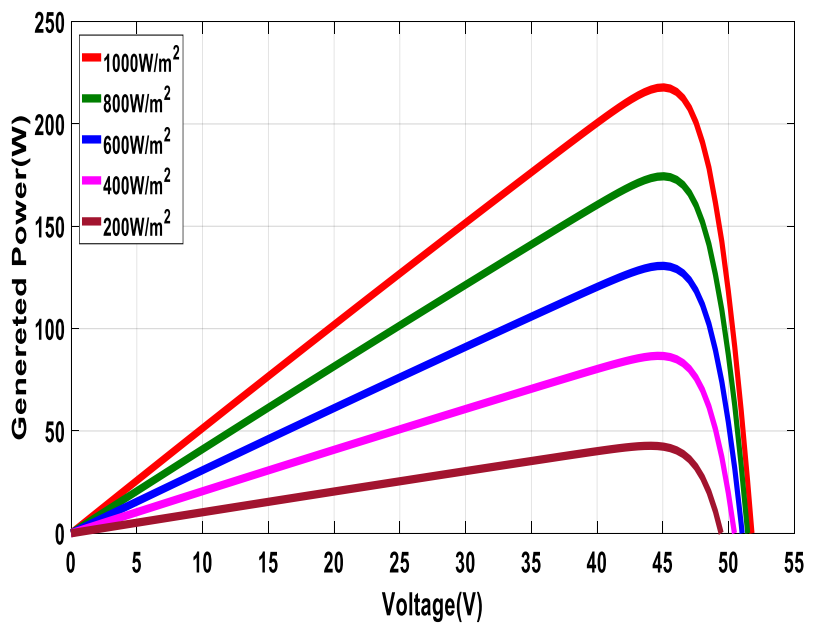

Fig. 9. Solar PV characteristics

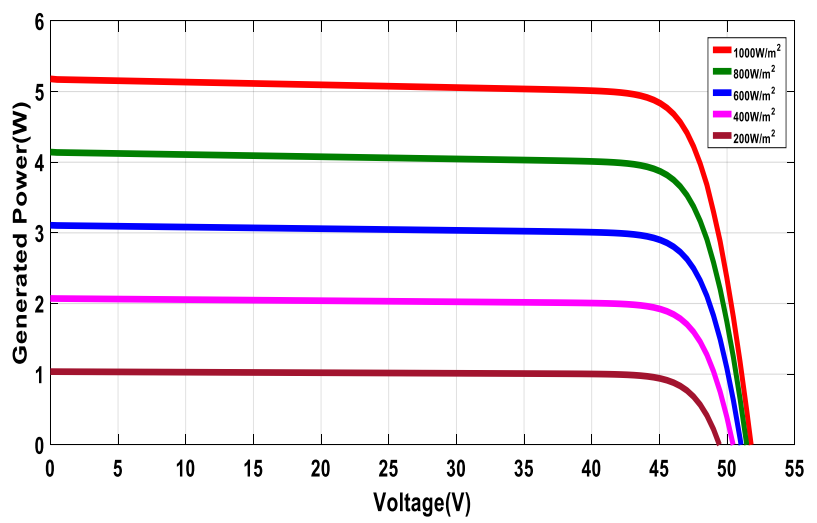

Fig. 10. Solar I-V characteristics

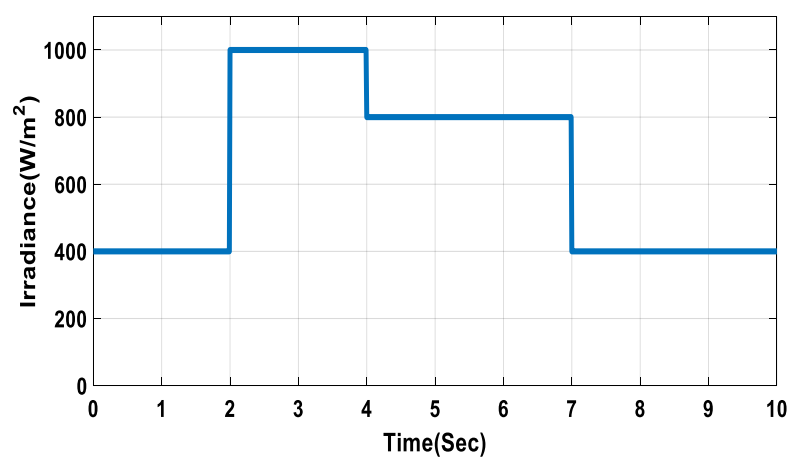

Fig. 11. A step change in solar irradiation command 


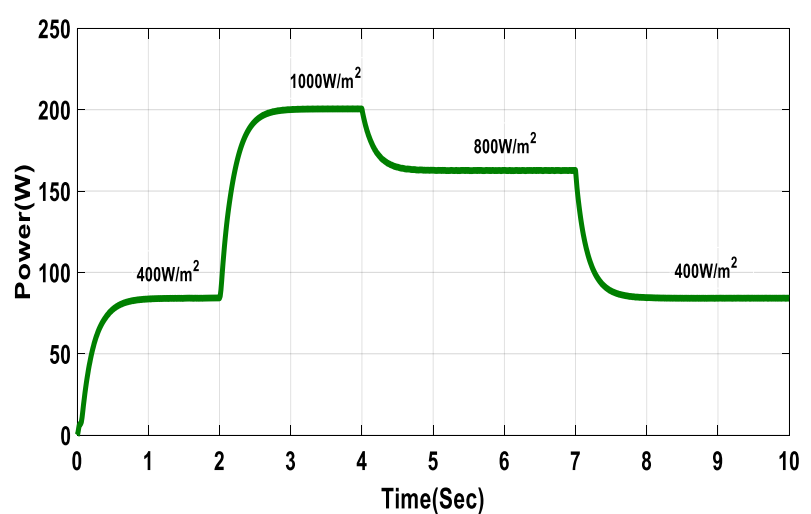

Fig. 12. MPPT curves for a step change in solar irradiation command

The implementation of the VMC is very simple with one loop compared to the ACMC. The ACMC is implemented with the inner current and outer voltage loops. The ACMC has distinctive advantages such as good dynamics, over current protection, and the absence of subharmonic oscillations. The block diagram of ACMC is shown in Fig. 13. The control transfer functions are shown in Eqs. (22) - (24).

$$
\begin{aligned}
& F(s)=\frac{628318}{(s+628318)} \\
& C_{1}(s)=\frac{0.1(1+10 s)}{s} \\
& C_{2}(s)=\frac{1500(1+0.01 s)}{s}
\end{aligned}
$$

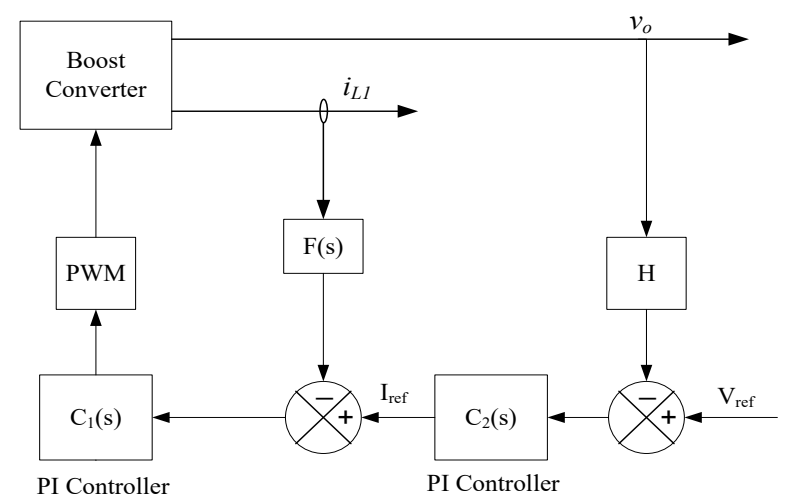

Fig. 13. Block diagram of ACMC

The line and load regulations are the fundamental issues in case of dc-dc converters. The line regulation is abided by the input voltage variations, whereas load regulation refers to the sudden changes in the load. In both the above issues, the output voltage will be severely effected in terms of transient voltage deviation (TVD) and transient settling time (TSD). After suffering a dip, the output voltage should reach steady state in a fraction of msec. The very low values of TVD and TST are possible through proper control parameter selection. Therefore, the design of PI controllers of the ACMC is essential for actualizing the good transient response and also robustness against the above mentioned regulations. The outer voltage loop generates a current reference based on the reference output voltage and the feedback voltage magnitude. The current loop error is passed through a PI controller for the generation of gating pulses to the MOSFET switches. The current loop filter corner freuency is less than the switching freuency. During short circuits, the current loop error becomes negative and thereby tends to maintain current with in the limits by decreasing the duty cycle of the dc-dc converter.

\subsection{VMC and ACMC based HGC performance for load variation at $45 \mathrm{~V}$}

Figs. 14 (a) \& (b) depict the performance waveforms of the VMC based HGC with TVDs during step-down (0.5 A - 0.1 A) and step-up load transitions $(0.1 \mathrm{~A}-0.5 \mathrm{~A})$ are $+1.25 \%$ and $-2 \%$ with TSTs of $100 \mathrm{msec}$ and $40 \mathrm{msec}$, Whereas the ACMC based HGC is exhibiting $+0.7 \%$ and $-0.45 \%$ with settling times of $35 \mathrm{msec}$ and $35 \mathrm{msec}$, respectively as shown in Figs. 15 (a) \& (b).

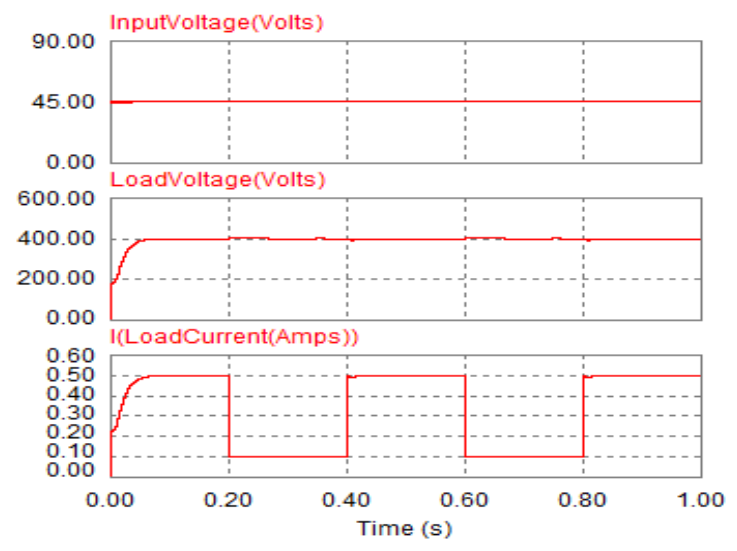

(a) Unmagnified

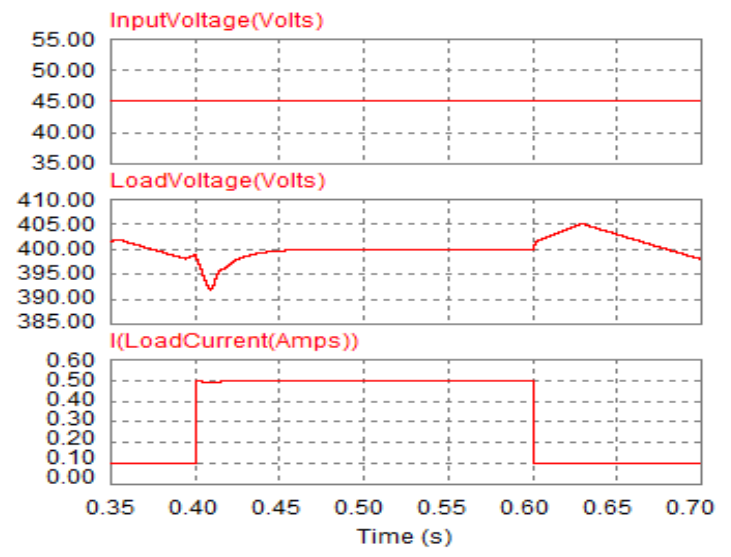

(b) Enlarged

Fig. 14. HGC waveforms with VMC for load variation at $45 \mathrm{~V}$

For the $45 \mathrm{~V}$ to $25 \mathrm{~V}$ step decrease in $\mathrm{V}_{\text {in }}$ at $0.5 \mathrm{msec}$, a sudden dip is observed in the output voltage waveform. If this dip persists for a long time, the loads connected to the HGC draws more current and aggrandises the power dissipation issues over the entire power system. In this case study, the ACMC exhibits excellent performance with a settling time of $55 \mathrm{msec}$ as compared to $80 \mathrm{msec}$ in the VMC. On the other hand, for $45 \mathrm{~V}$ to $120 \mathrm{~V}$ step increase in the $\mathrm{V}_{\text {in }}$, the output voltage rises to a dangerous value causing severe voltage stresses on the semiconductor devices besides the insulation breakdown issues. Therefore, the converter should be designed with sufficient bandwidth for restoring the normal conditions. Here also, the ACMC based HGC exhibits excellent performance with a settling time of $220 \mathrm{msec}$ as compared to $300 \mathrm{msec}$ in the case of the VMC based HGC. 


\subsection{VMC and ACMC based HGC performance for load} variation at $25 \mathrm{~V}$

Section 3.1 presents the performance analysis at steady input voltage of $45 \mathrm{~V}$. However, the converter input voltage undergoes variations and affects the HGC performance. This may be due to the variations either in the solar irradiations or FC internal parameters. This section highlights the performance analysis of the converter at a steady dc input voltage of 25 V. Figs. 16 (a) \& (b) depict the performance waveforms of the VMC based HGC with TVDs during stepdown $(0.5 \mathrm{~A}-0.1 \mathrm{~A})$ and step-up load transitions $(0.1 \mathrm{~A}-$ $0.5 \mathrm{~A})$ are $+5 \%$ and $-5 \%$ with settling times of $100 \mathrm{msec}$ and $100 \mathrm{msec}$, respectively. Whereas the ACMC based HGC is exhibiting $+1 \%$ and $-0.7 \%$ with $20 \mathrm{msec}$ and $20 \mathrm{msec}$, respectively as shown in Figs. 17 (a) \& (b).

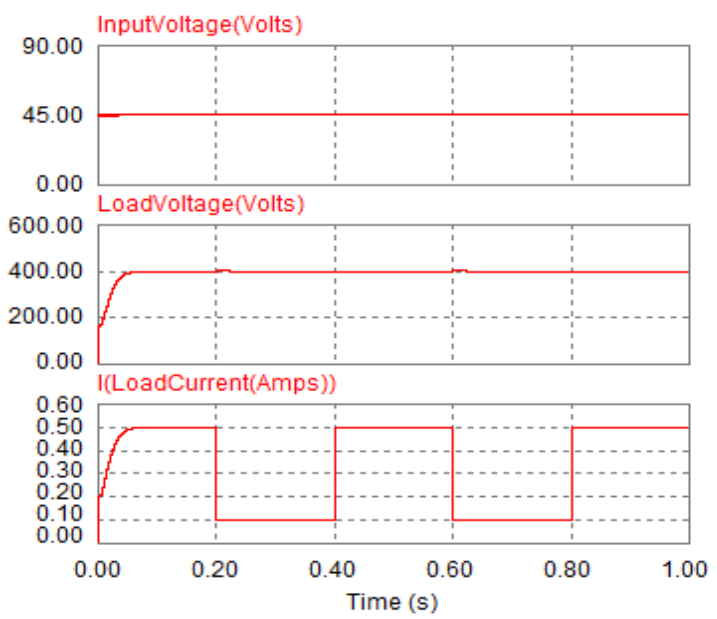

(a) Unmagnified

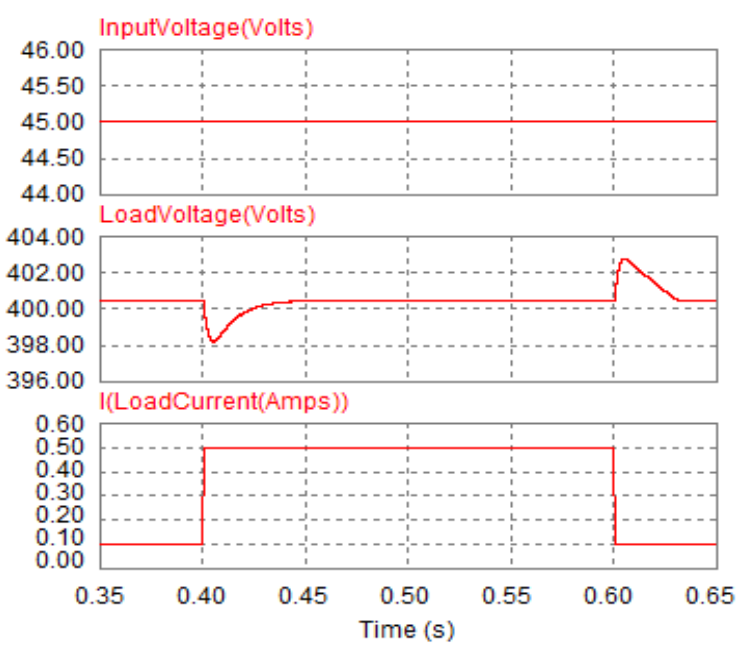

(b) Enlarged

Fig. 15. HGC waveforms with ACMC for load variation at $45 \mathrm{~V}$

With ACMC, even under worst input voltage condition of $25 \mathrm{~V}$, the TVDs are lying around the standard limit of $5 \%$ as compared to $2 \%$ at $45 \mathrm{~V}$. Moreover, the TST of $20 \mathrm{msec}$ is comparable with that of the value of $35 \mathrm{msec}$ at $45 \mathrm{~V}$. However, small oscillations are observed in the output waveforms. Thus, the HGC performance with ACMC is superior even under worst operating conditions as compared to the VMC.
3.3 VMC and ACMC based HGC performance with step input voltage

Section 3.1 and Section 3.2 present the load regulation analysis at steady input voltages of $45 \mathrm{~V} \& 25 \mathrm{~V}$. This section describes the line regulation analysis of $\mathrm{HGC}$ at constant load current of 0.5 A. Figs. 18 (a) \& (b) present the performance waveforms of the VMC, whereas the ACMC performance is shown in Figs. 19 (a) \& (b), considering two different case studies with step input voltages.

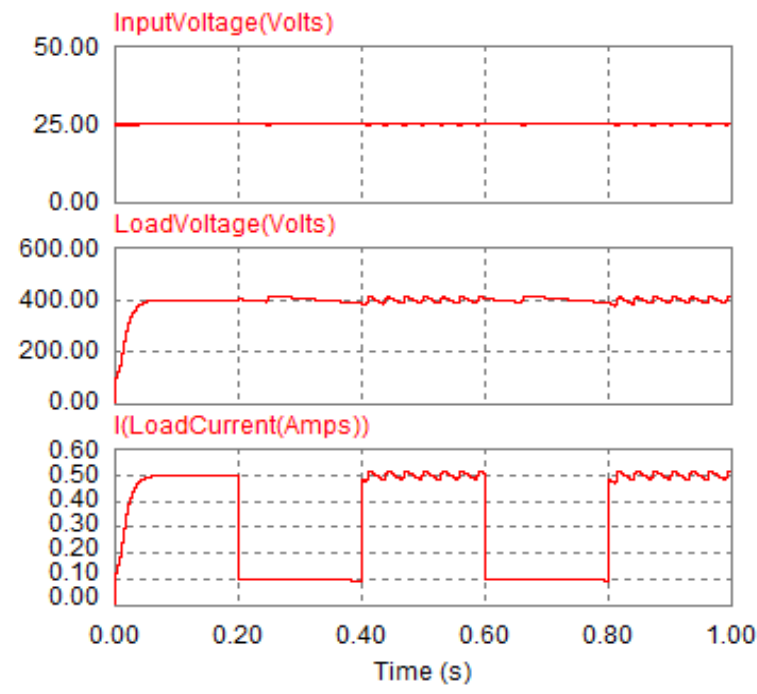

(a) Unmagnified

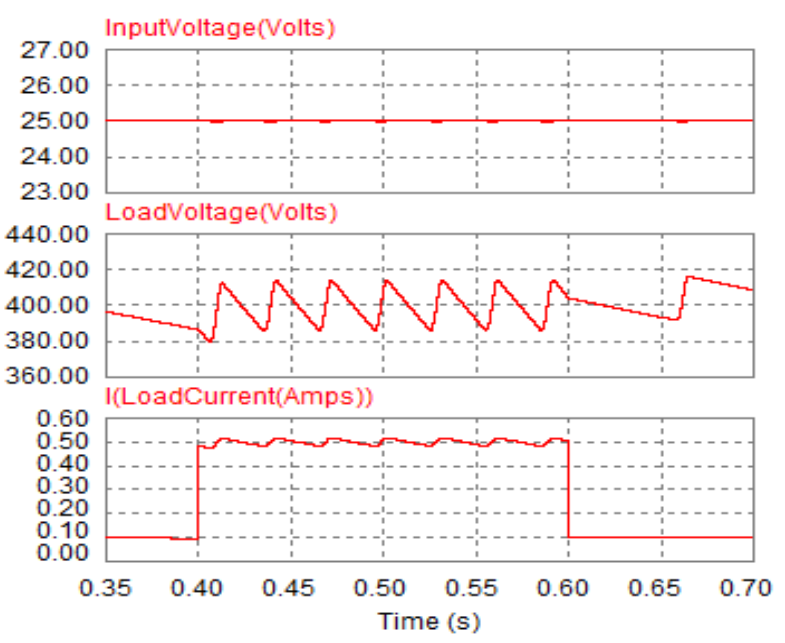

(b) Enlarged

Fig. 16. HGC waveforms with VMC for load variation at $25 \mathrm{~V}$

3.4 Input current ripple at input voltages of $45 \mathrm{~V} \& 25 \mathrm{~V}$ This section highlights the issues associated with the lifetime of the FCs as well as the solar PV panels. The FCs are highly sensitive to the current ripples. The increased current ripple can degrade the lifetime and efficiency of the FC stack. On the other hand, the current ripple curtails the maximum power available from the solar panel. It is also responsible for a drift in the maximum power point (MPP). The operating frequency of the converter plays a key role in minimizing the current ripples. At an input voltage of $45 \mathrm{~V}$, the input current ripple is found to be $59.1 \%$ in the case of ACMC based HGC as compared to $81.8 \%$ with the VMC based HGC as shown in Fig. 20 (a) \& Fig. 21 (a). For the $25 \mathrm{~V}$ input, the input current ripple is found to be $18.75 \%$ with the ACMC based HGC as 
compared to $25 \%$ in case of the VMC based HGC as shown in Fig. 20 (b) \& Fig. 21 (b). Therefore, the reduced current ripple can enhance the lifetime and reliability of the FC stack as well as the solar panel.

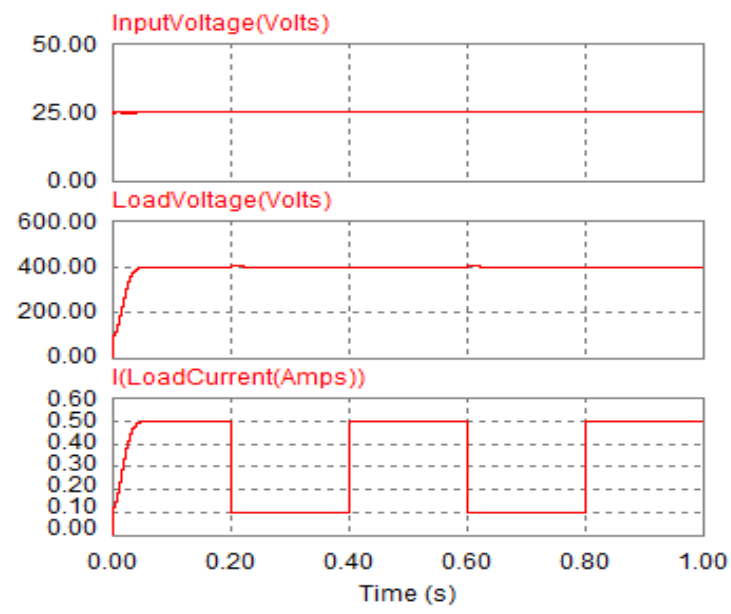

(a) Unmagnified

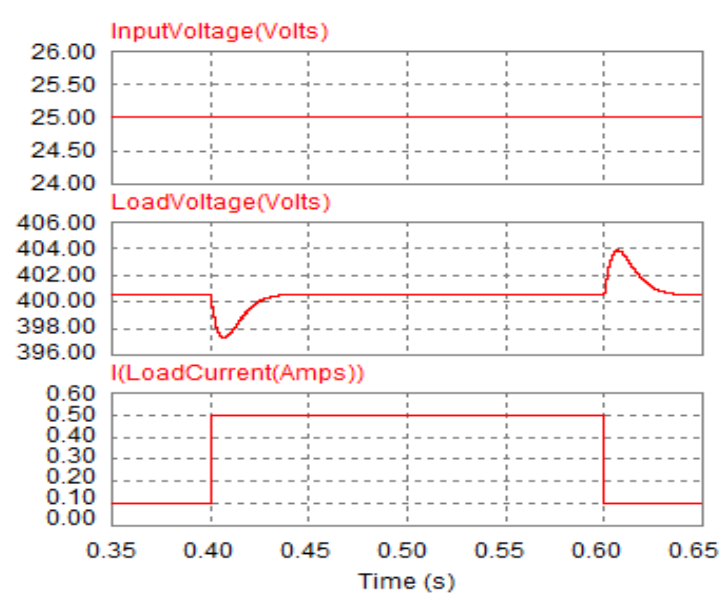

(b) Enlarged

Fig. 17. HGC waveforms with ACMC for load variation at $25 \mathrm{~V}$

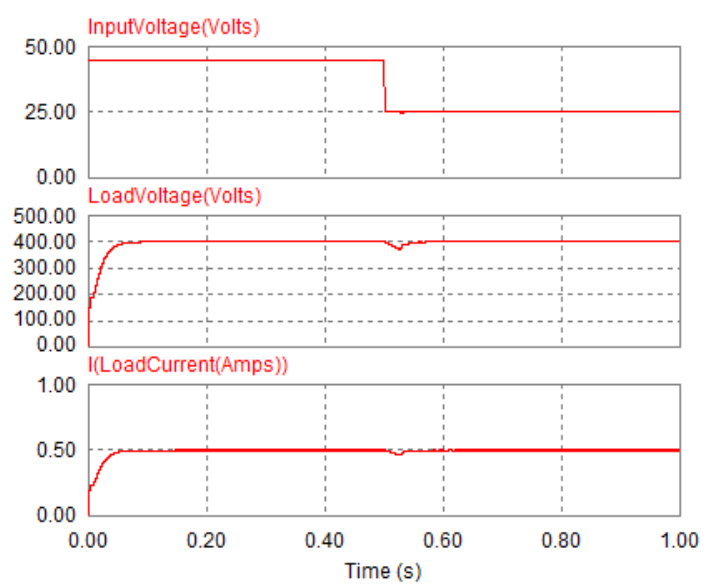

(a)

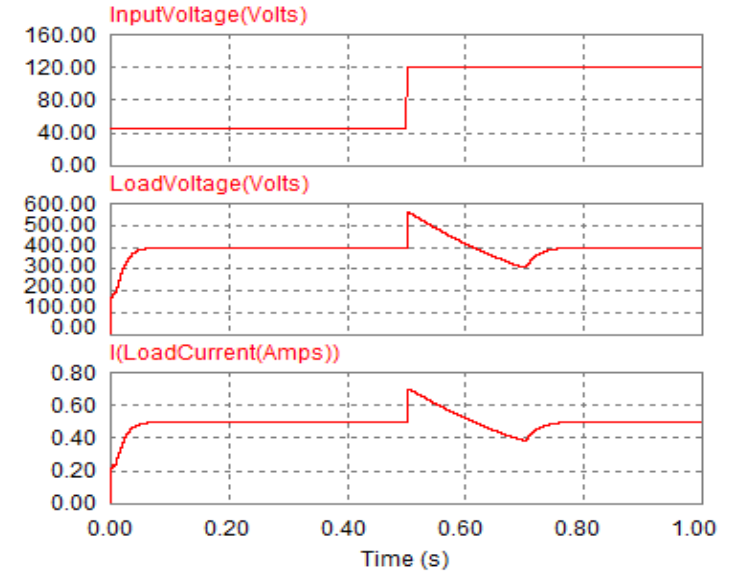

(b)

Fig. 18. HGC waveforms with VMC (a) $45 \mathrm{~V}$ to $25 \mathrm{~V}$ (b) $45 \mathrm{~V}$ to $120 \mathrm{~V}$

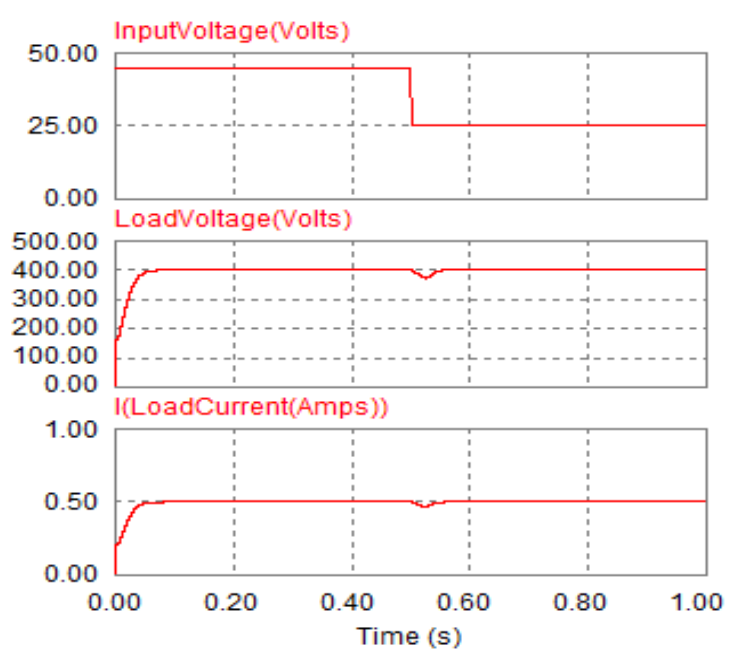

(a)

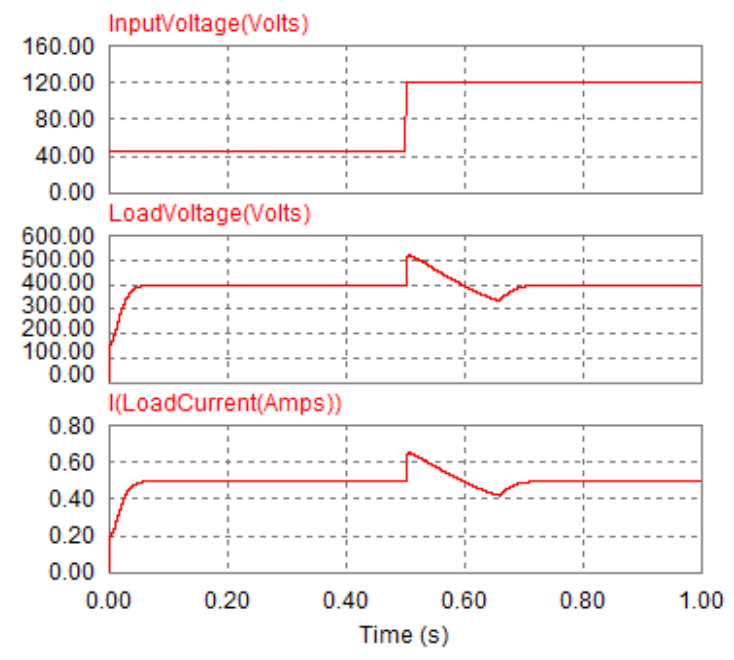

(b)

Fig. 19. HGC waveforms with ACMC (a) $45 \mathrm{~V}$ to $25 \mathrm{~V}$ (b) $45 \mathrm{~V}$ to 120 V 


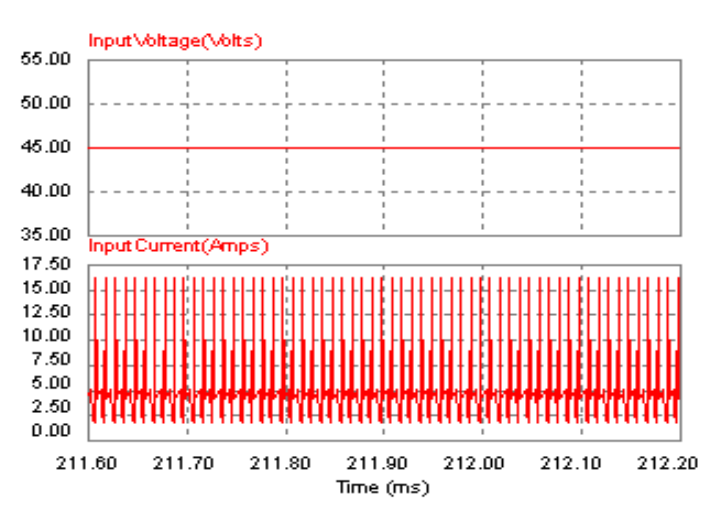

(a)

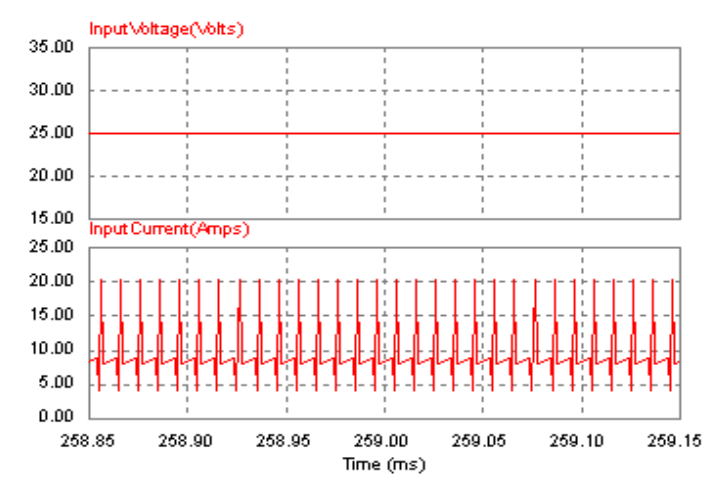

(b)

Fig. 20. HGC waveforms with VMC (a) $45 \mathrm{~V}$ (b) $25 \mathrm{~V}$

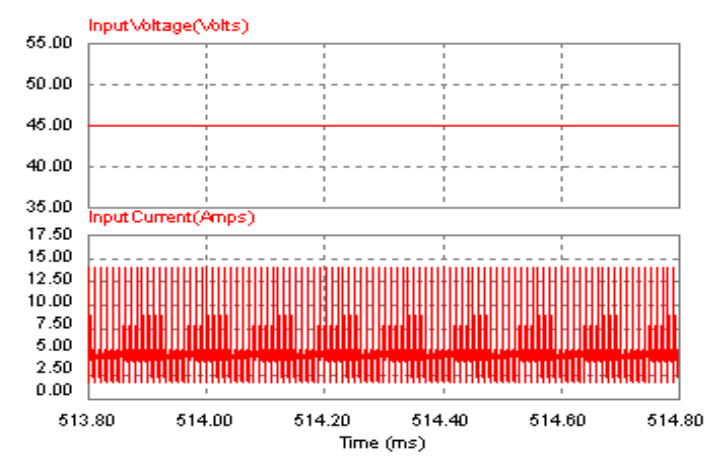

(a)

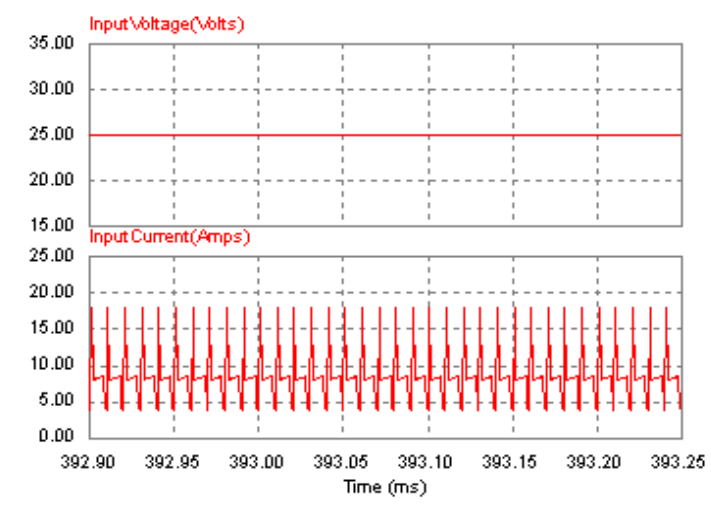

(b)

Fig. 21. HGC waveforms with ACMC (a) $45 \mathrm{~V}$ (b) $25 \mathrm{~V}$

Table 4 and Table 5 show the HGC performance at $45 \mathrm{~V}$ and $25 \mathrm{~V}$ inputs for analysing the transient performance during step-up and step-down load dynamics. With ACMC, the TST is observed to be $20 \mathrm{msec}$ even at reduced converter input voltage of $25 \mathrm{~V}$ as compared to the $35 \mathrm{msec}$ at $45 \mathrm{~V}$ input. Table 6 shows the HGC performance with step input voltages of $45 \mathrm{~V}$ to $25 \mathrm{~V} \& 45 \mathrm{~V}$ to $120 \mathrm{~V}$ at a constant load current of $0.5 \mathrm{~A}$. The results have proven the good transient performance with settling times of $55 \mathrm{msec}$ and $220 \mathrm{msec}$ in case of the ACMC as compared to $80 \mathrm{msec} \& 300 \mathrm{msec}$ with the $\mathrm{VMC}$.

Table 4. HGC performance during step-up load transient

\begin{tabular}{l|l|l|l|l}
\hline & \multicolumn{2}{|l|}{ VMC based HGC } & \multicolumn{2}{|l}{ ACMC based HGC } \\
\hline $\begin{array}{l}\text { Input } \\
\text { voltage }\end{array}$ & TVD & $\begin{array}{l}\text { TST } \\
(\mathbf{m s e c})\end{array}$ & TVD & $\begin{array}{l}\text { TST } \\
\text { (msec) }\end{array}$ \\
\hline $45 \mathrm{~V}$ & $-8 \mathrm{~V}$ & 40 & $\begin{array}{l}-1.8 \mathrm{~V} \\
(0.45 \%)\end{array}$ & 35 \\
& $(2 \%)$ & & $\begin{array}{l}-2.8 \mathrm{~V} \\
(0.7 \%)\end{array}$ & 20 \\
\hline
\end{tabular}

Table 5. HGC performance during step-down load transient

\begin{tabular}{l|l|l|l|l}
\hline & \multicolumn{2}{|l|}{ VMC based HGC } & \multicolumn{2}{l}{ ACMC based HGC } \\
\hline $\begin{array}{l}\text { Input } \\
\text { voltage }\end{array}$ & TVD & $\begin{array}{l}\text { TST } \\
(\mathbf{m s e c})\end{array}$ & TVD & $\begin{array}{l}\text { TST } \\
(\mathbf{m s e c})\end{array}$ \\
\hline $45 \mathrm{~V}$ & $+5 \mathrm{~V}$ & 100 & $+2.8 \mathrm{~V}$ & 35 \\
& $(1.25 \%)$ & & $(0.7 \%)$ & \\
$25 \mathrm{~V}$ & $+20 \mathrm{~V}$ & 100 & $+4 \mathrm{~V}(1.0 \%)$ & 20 \\
& $(5.0 \%)$ & & & \\
\hline
\end{tabular}

Table 6. HGC performance during line regulation

\begin{tabular}{l|l|l|l|l}
\hline & \multicolumn{2}{|l|}{ VMC based HGC } & \multicolumn{2}{l}{ ACMC based HGC } \\
\hline $\begin{array}{l}\text { Input } \\
\text { voltage }\end{array}$ & TVD & $\begin{array}{l}\text { TST } \\
(\mathbf{m s e c})\end{array}$ & TVD & $\begin{array}{l}\text { TST } \\
\text { (msec) }\end{array}$ \\
\hline $45 \mathrm{~V}$ to 25 & $-30 \mathrm{~V}$ & 80 & $-27.5 \mathrm{~V}$ & 55 \\
$\mathrm{~V}$ & $(7.5 \%)$ & & $(6.8 \%)$ & \\
$45 \mathrm{~V}$ to 120 & $+50 \mathrm{~V}$ & 300 & $\begin{array}{l}+20 \mathrm{~V} \\
(5.0 \%)\end{array}$ & 220 \\
$\mathrm{~V}$ & $(12.5 \%)$ & & \multicolumn{2}{|c}{} \\
\hline
\end{tabular}

Table 7 shows the input current ripple of $\mathrm{HGC}$ with VMC and $\mathrm{ACMC}$ at different input voltage conditions of $45 \mathrm{~V}$ and $25 \mathrm{~V}$, with a constant load current of $0.5 \mathrm{~A}$. The ACMC based HGC is phenomenal in transient as well as steady operating conditions as compared to VMC based HGC.

Table 7. HGC performance for input current ripple

\begin{tabular}{l|l|l}
\hline Input voltage & VMC based HGC & ACMC based HGC \\
\hline $45 \mathrm{~V}$ & $81.8 \%$ & $59.1 \%$ \\
$25 \mathrm{~V}$ & $25 \%$ & $18.75 \%$ \\
\hline
\end{tabular}

\section{Conclusion}

This paper presents the exhaustive performance analysis of hybrid power sourced high gain step-up converter for electric vehicles and industrial applications. This converter can be fed either from a solar panel or a fuel cell stack. The fuel cell polarisation characteristics are shown with much more emphasis on the temperature effects. The solar panel performance curves are shown at different solar irradiation levels. The maximum power point tracking controller has realized the good transient response with a settling time of few msec. The PSIM simulation study includes different case studies in view of line and load regulations using the voltagemode and average-current mode control strategies. It includes the dynamic performance indices like the transient voltage deviation and the transient settling time. The average currentmode control strategy is dominant with excellent dynamic performance as compared to the voltage mode control strategy. The reduced input current ripples can enhance the lifetime of the power sources as well as the power conditioning units of the proposed hybrid power system. This work can be further extended for high power applications along with the incorporation of advanced control strategies. 
This is an Open Access article distributed under the terms of the Creative Commons Attribution License.

\section{References}

1. F. M. Guangul, and G. T. Chala. Solar Energy as Renewable Energy Source: SWOT Analysis. 2019 4th MEC International Conference on Big Data and Smart City (ICBDSC), Muscat, Oman, pp. 1-5 (2019).

2. Y. Ravindranath Tagore, K. Anuradha, A. R. Vijay babu, and P. Manoj Kumar. Modelling, simulation and control of a fuel cell powered laptop computer voltage regulator module. Int J Hydrogen Energy, 44(21), pp. 11012-19 (2019).

3. D. Himadry Shekhar, T. Chee Wei, and A. H. M. Yatim. Fuel cell hybrid electric vehicles: A review on power conditioning units and topologies. Renewable and Sustainable Energy Reviews, 76(1), pp. 268-291 (2017).

4. Y. Zhang, J. Shi, L. Zhou, Jing Li, M. Sumner, P. Wang, and C. Xia. Wide Input-Voltage Range Boost Three-Level DC-DC Converter With Quasi-Z Source for Fuel Cell Vehicles. IEEE Transactions on Power Electronics, 32(9), pp. 6728-6738 (2017).

5. Y. Zhang, C. Fu, M. Sumner, and P. Wang. A Wide Input-Voltage Range Quasi-Z-Source Boost DC-DC Converter With High-Voltage Gain for Fuel Cell Vehicles. IEEE Transactions on Industrial Electronics, 65(6), pp. 5201-5212 (2018).

6. F. Kardan, R. Alizadeh, and M. R. Banaei. A New Three Input DC/DC Converter for Hybrid PV/FC/Battery Applications. IEEE Journal of Emerging and Selected Topics in Power Electronics, 5(4), pp. 1771-1778 (2017).
7. Y. Zhang, L. Zhou, M. Sumner, and P. Wang. Single-Switch, Wide Voltage-Gain Range, Boost DC-DC Converter for Fuel Cell Vehicles. IEEE Transactions on Vehicular Technology, 67(1), pp. 134-145 (2018).

8. E. H. Ismail, M. A. Al-Saffar, A. J. Sabzali, and A. A. Fardoun. A Family of Single-Switch PWM Converters With High Step-Up Conversion Ratio. IEEE Transactions on Circuits and Systems I: Regular Papers, 55(4), pp. 1159-1171 (2008).

9. G. Wu, X. Ruan, and Z. Ye. Nonisolated High Step-Up DC-DC Converters Adopting Switched-Capacitor Cell. IEEE Transactions on Industrial Electronics, 62(1), pp. 383-393 (2015).

10. R. T. Yadlapalli, and A. Kotapati. Modelling, design and implementation of quadratic buck converter for low power applications. Int. J. of Power Electronics, 11(3), pp.322-3389 (2020).

11. G. Ganesh, G. Vijay Kumar, A. R. Vijay Babu, G. Srinivasa Rao, and Y. Ravindranath Tagore. Performance analysis and MPPT control of a standalone hybrid power generation system. Journal of electrical engineering. 15(1), pp. 334-343 (2015).

12. [12] Y. Ravindranath Tagore, and K. Anuradha. Modeling and control of laptop computer voltage regulator module with multiple power sources. Journal Européen des Systèmes Automatisés, 53 (3), pp. 421-427 (2020). 